DOI 10.4467/25439561KSR.18.016.9662

BożenA PINDUS (D) https://orcid.org/0000-0002-0507-731X

Uniwersytet Humanistyczno-Przyrodniczy im. Jana Długosza

Częstochowa

\title{
„DON KICHOT W ZNISZCZONYM FRAKU”, CZYLI O HEROIZMIE DOKTORA FRIEDRICHA HAASSA ${ }^{2}$
}

\section{"DON KICHOT IN A WORN-OUT TAILCOAT" - ABOUT THE HEROISM OF DOCTOR FRIEDRICH HAASS}

\section{Streszczenie}

Początek wieku dziewiętnastego w Rosji charakteryzował się prawem szczególnie bezwzględnym wobec przestępców i osób, które w jakikolwiek sposób sprzeniewierzyły się władzy państwowej. Ciężkie więzienia, zesłania i surowe warunki traktowania aresztantów wpisane były na stałe w obraz systemu kar za konflikt z prawem. Pojawienie się w roku 1806 w Moskwie niemieckiego lekarza Friedricha Haassa, który jako jeden z pierwszych wezwał do miłosiernego traktowania skazańców, stało się zwrotnym punktem w podejściu do zesłańców i przestępców w carskiej Rosji.

Niniejszy artykuł przypomina postać heroicznego doktora, który głosząc dewizę ,Spieszcie się czynić dobro", sprzeciwiał się bezdusznym rosyjskim urzędnikom, przeznaczał własne pieniądze na wcielanie w życie reformy więziennictwa, wysyłał pisma piętnujące istniejący system do najwyższych władz rosyjskich, w tym do cara. Wytrwałość, skuteczność działania, poświęcenie dla najsłabszych i pokrzywdzonych oraz bezinteresowność Haassa imponowały jego otoczeniu, dla którego postawa doktora była przykładem prawdziwie chrześcijańskiego podejścia do kwestii współczucia, poświęcenia i sprawiedliwości. Zasługi Friedricha Haassa zapewniły mu trwałe miejsce nie tylko w historii rosyjskiej medycyny, ale także w literaturze pięknej w Rosji. Kościół katolicki ogłosił go w 2018 roku błogosławionym.

\footnotetext{
${ }^{1}$ Określenie pochodzi od Lwa Kopielewa. Zob. Л. Копелев, Святой доктор Федор Петрович, Москва, Центр книги Рудомино, 2013, s. 131.

${ }^{2}$ Oryginalna pisownia nazwiska doktora to Haass, ale spotykana jest również forma Haas.
} 


\begin{abstract}
The beginning of the 19th century in Russia was characterized with the enactment of law. It was particularly ruthless regarding to criminals and people who were disloyal to the authorities. Hard prisons, exiles, and harsh treatment of the convicted were permanently included in the outlook of the system of penalties, for example the infringement of law. Moscow arrival of doctor Friedrich Haass in 1806, who as one of the first summoned to merciful treatment of the convicted, became the turning point of the attitudes to the exiled and the sentenced in the Tsar's Russia.

This article reminds the person of the heroic Doctor, who advocated the motto "Hurry up to make the good" opposed soulless Russian officials, providing own resources on undertaking reforms of the prison system, sending letters to the highest authorities (including Tsar), opposing the functioning system. Haass's persistence and effectiveness of action, sacrifice towards the weakest and lack of interestedness impressed the surrounding, for which the attitude of the doctor was an example of truly Christian approach to the question of sympathy, sacrifice and justice. Then, the contributions of Haass assured him a permanent recognition not only in the history of Russian medicine, but also in the belles-lettres of Russia. Catholic Church proclaimed him blessed in 2018.
\end{abstract}

Słowa kluczowe: Rosja, wiek XIX, doktor Friedrich Haass, zesłanie, skazańcy, organizacje charytatywne

Keywords: Russia, 19th century, Doctor Friedrich Haass, exile, convicted, charity organisations

Nazywano go „więziennym doktorem”, ,szalonym filantropem”3, „przyjacielem nędzarzy”, ,dobrym doktorem”, „przyjacielem nieszczęśliwych”5, „Bożym człowiekiem”, ,człowiekiem poświęcenia”, w końcu przylgnął do niego przydomek ,święty doktor"8. Nie ulega wątpliwości, że Friedrich Joseph Haass, niemiecki lekarz,

${ }^{3}$ Ю. Феофанов, „Тюремный доктор” Федор Петрович Гааз, „Российская Федерация сегодня: Общественно-политический журнал Федерального собрания парлямента РФН” 2007, $\mathrm{nr} 22$, ss. 58-59; Е. Каликинская, Тюремный доктор Гааз: безумный филантроп и помощник осужденных, „Аргументы и факты” 2013, nr 45, [w:] http://www.aif.ru/society/history/1017397 [dostęp: 20.05.2018]; tłumaczenie z języka rosyjskiego własne. Tam, gdzie nie zaznaczono inaczej wszystkie tłumaczenia z języków obcych pochodzą od autorki niniejszego artykułu B.P.

${ }^{4}$ Г. Петров, Ф.П. Гааз. Друг обездоленных, Москва, Сытин, 1902.

${ }^{5}$ А. Сосницкий, „Добрый доктор”, „, друг несчастных” Федор Петрович Гааз, Москва, Оксаковская, 1900.

${ }^{6}$ Аноним, ,Божий человек” доктор Гааз, „Истина и жизнь” 1992, nr 4, ss. 34-38.

${ }^{7}$ Н. Щемелева, Доктор Ф.П. Гааз - человек подвига, „Филокартия” 2015, февраль, nr 1 (41), ss. 42-43.

${ }^{8}$ Н.Э. Вашкау, ,Святой доктор” Федор Петрович Гааз, „Вестник Волгоградского государственного университета. Серия 4. История” 2012, nr 2 (22), ss. 26-31. 
który przybył w roku 1806 do Rosji był człowiekiem nietuzinkowym. W Rosji nazywano go Fiodorem Piotrowiczem (ojciec Haassa miał na imię Piotr).

Doktor Fiodor Piotrowicz urodził się 10 sierpnia w 1780 roku w pobliżu Kolonii w małym miasteczku Bad - Münstereifel. Jego dziadek był chirurgiem, ojciec aptekarzem, z domu rodzinnego Haass wyniósł więc tradycje leczenia i pomagania chorym oraz potrzebującym i poszedł w ślady swoich przodków, podejmując studia medyczne, które odbywał na uniwersytetach w Jenie, Getyndze, a także w Wiedniu. Został lekarzem kilku specjalności, w tym chirurgii i okulistyki. Ta ostatnia przyniosła mu sławę, kiedy w Wiedniu udało mu się wyleczyć księżnę Repninę z domu Rosenmacher ze skomplikowanej choroby oczu. Zachwycona pacjentka zaprosiła Haassa do Rosji w charakterze swojego lekarza rodzinnego. Umowa podpisana z księżną przewidywała, że Haass będzie pracował dla niej, jej rodziny i służby przez 4 lata, od roku 1806 do 1810: „nie tylko w mieście Petersburgu, ale także na wsi i wszędzie, gdzie Jej Miłość będzie się znajdować"9. Za pracę doktor miał otrzymać mieszkanie, zaopatrzenie, wyżywienie, służbę oraz 2000 rubli rocznie. Po upływie wskazanego okresu zatrudnienia umowa przewidywała dodatkowe wynagrodzenie 200 dukatów na pokrycie kosztów podróży powrotnej doktora do Niemiec. Co ważne, praca u księżnej nie zamykała niemieckiemu doktorowi możliwości leczenia innych osób pod warunkiem, że dodatkowa praktyka lekarska nie będzie kolidować z obowiązkami wobec pozostającej pod opieką Haassa jego protektorki ${ }^{10}$.

Fiodor Piotrowicz okazał się znakomitym fachowcem, pomagającym w przypadkach, wobec których inni lekarze pozostawali bezradni. Wśród pacjentów doktora byli ludzie bardzo majętni, dzięki którym Haass się wzbogacił. Jako utalentowany i skuteczny doktor, dorobił się własnego pałacu, licznej służby, karet, koni. Miał nawet własną fabrykę. Trafiali do niego też biedacy, których leczył zawsze za darmo. Poza praktyką lekarską Haass zajmował się także teorią medycyny, pracował nad problemami równowagi fizjologicznej organizmu, interesował się leczeniem dyfterytu i uczynił w tej kwestii wiele dla pediatrii. Nieocenione zasługi oddał także klimatologii, balneologii i klimatoterapii. Zajmował się kompleksowo studiami nad wodami mineralnymi i gorącymi źródłami Kaukazu, poddając analizie ich właściwości prozdrowotne i lecznicze. Zbadał, między innymi, i opisał słynne do dziś źródła mineralne ze złóż w miejscowości Żeleznyje Wody, Kisłowodzk oraz w Jessientukach. Niektórym źródłom nadawał własne nazwy, które funkcjonują w Rosji do dziś. Swoje refleksje i wnioski z wypraw na Kaukaz Haass zawarł w opublikowanej w roku 1811 rozprawie Moja podróż do wód Aleksandrowskich w latach 1809-1810

\footnotetext{
9 Л. Копелев, Святой доктор Федор Петрович, ор.cit., s. 22.

${ }^{10}$ Ibidem.
} 
(Ma visite aux eaux d'Alexandre en 1809 et 1810) ${ }^{11}$. Niewątpliwą zasługą doktora Friedricha Haassa dla podniesienia poziomu opieki medycznej było zorganizowanie przez niego pierwszego pogotowia w Moskwie ${ }^{12}$.

Kontrakt z księżną Riepniną wygasł doktorowi Haassowi w roku 1810, jednakże Fiodor Piotrowicz nie zdecydował się opuścić Rosji i, jak się potem okazało, pozostał w niej już do końca życia. W czasie wojny z Napoleonem w 1812 roku Haass pracował na rzecz armii rosyjskiej jako chirurg wojskowy. Z żołnierzami brał też udział w przemarszu do Paryża ${ }^{13}$.

Z końcem 1820 roku Fiodor Piotrowicz zaczął stopniowo odchodzić od dochodowej praktyki lekarskiej, a jego uwagę coraz bardziej pochłaniali chorzy biedacy, wyrzutkowie społeczni, aresztanci, a przede wszystkim udający się na Syberię przez Moskwę zesłańcy. Ci ostatni budzili litość doktora nie tylko z powodu ich położenia, ale również ze względu na okrutne warunki ich transportowania do miejsca przeznaczenia. Przejęty dolą osób skazanych na katorgę, Haass zaczął intensywnie pracować na rzecz poprawy ich sytuacji ${ }^{14}$. Zesłańcy przemieszczający się na Syberię przez Moskwę mieli postój na Worobiowych Wzgórzach. Tam pojawiał się Haas, badał aresztantów, oddzielał chorych od zdrowych i, jeśli stan fizyczny tych pierwszych wymagał pomocy medycznej, starał się o pozostawienie ich na leczenie w szpitalu. Opatrywał także rany, które powstawały na rękach i nogach więźniów na skutek otarć, których dokonywały żelazne kajdany. Przez wiele lat Haass orędował u władz rosyjskich za zmianą formy i wagi kajdan. W końcu sam je zrekonstruował, wypróbował na własnym ciele i rozpoczął walkę o ich zastosowanie dla zesłańców. Po długich staraniach Haassowi udało się przekonać władze rosyjskie, by nie tylko zmniejszyć wagę kajdan, ale także w miejscach kontaktu ze skórą człowieka wyściełać je tkaniną lub skórą, dzięki czemu nie raniły one rąk i nóg zesłańców tak bardzo, jak to miało miejsce wcześniej. Nowe kajdany - nazywano je „haassowskimi” (гаaзовские) lub „kajdanami doktora Haassa” - wykuwano w kuźni, którą Fiodor Piotrowicz polecił wybudować $\mathrm{z}$ własnych środków ${ }^{15}$. Stosowano je wobec tych, którzy skazani byli za poważne przestępstwa. Inne transportowane osoby przywiązywano do tak zwanego pręta (прут). Ten, który stosowano w czasach Haassa usan-

${ }^{11}$ Zob. F. Haass, Ma visite aux eaux d'Alexandre en 1809 et 1810, изд. Всеволожского, 1811.

${ }^{12}$ Zob. А. Грандо, Федор Гааз: Счастье - делать счастливым других, „Медицинская газета” 1977, nr 61, s. 11; М.А. Мессель, Из истории скорой медицинской помощи в России, „Советское здравохранение" 1960, nr 9, ss. 53-58.

${ }^{13}$ Zob. В. Варжапетян, 10 интересных фактов о докторе Гаазие, [w:] http://xn--80aqecdrlilg. xn--p1ai//doktor-gaaz / [dostęp:10.05.2018].

${ }^{14}$ Zob. А.Ф. Кони, Федор Петрович Гааз. Библиографический очерк, Москва, Сестричество во имя преподобномученицы великой княгини Елизаветы, 2006, ss. 7-8.

${ }^{15}$ Zob. В. Варжапетян, 10 интересных фактов о докторе Гаазе, ор.cit. 
kcjonował dla więźniów Naczelnik Głównego Sztabu Iwan Dybicz w roku 1824. Zdaniem doktora, ta forma ograniczania możliwości ucieczki więźniów była bardziej dotkliwa od kajdan. Paradoksalnie stosowano ją wobec ludzi, którzy nie popełnili ciężkich przestępstw, między innymi wobec chłopów zesłanych przez swoich panów za nieposłuszeństwo lub za utratę paszportu. Uciążliwość pręta polegała na tym, że przywiązywano do niego ludzi różnej płci, różnego wzrostu i odmiennej kondycji fizycznej. Skazani byli oni na siebie w czasie drogi, snu, ale także w trakcie zaspokajania potrzeb fizjologicznych, gdyż nigdy ich nie wypinano z pręta. Transportowanego więźnia uwalniano tylko w jednym przypadku - gdy okazywał się martwy. Pręt nie pozwalał na żadną intymność, możliwość bycia samemu ${ }^{16}$. To nieliczenie się z poczuciem wstydu uwięzionych, traktowanie ich na równi ze zwierzętami budziło przerażenie doktora. Haass bardzo starał się zmienić ten stan rzeczy, a dzień, w którym udało mu się wybłagać zastapienie pręta indywidualnymi kajdanami doktor uznał za jeden z najszczęśliwszych w swoim życiu ${ }^{17}$. Haass dokonał jeszcze jednej ważnej rzeczy w stosunku do zesłańców. Udało mu się doprowadzić do tego, że osoby chore i słabe mogły być wypięte z kajdan, co ułatwiało więźniom poruszanie się i nie uszkadzało ich ciał. Swoje kajdany musiały jednak nieść w specjalnych workach ${ }^{18}$.

Na co dzień Haass spotykał się najczęściej z bezdusznością urzędników, biurokratyczną rutyną, a przede wszystkim bezwzględnością ustawodawców oraz brakiem współczucia wobec skazańców. Niżsi urzędnicy poniżali także samego Haassa, posuwali się do opowiadania aresztantom o tym, że niektóre niedogodności, które przychodzi im znosić wymyślił dla nich niemiecki lekarz pojawiający się na Worobiowych Wzgórzach, zapewniali, że to jemu powinni być „wdzięczni” za złe traktowanie i "haassowskie” kajdany ${ }^{19}$. Często więźniowie i aresztanci, którzy nie mieli wiedzy o poprzedniej formie kajdan, przeklinali Haassa, życząc mu wszystkiego najgorszego. Mimo to doktor nie przestawał prowadzić podjętej przezeń walki. Jego sława medyczna, znajomości w kręgach arystokracji często otwierały drzwi, które wydawały się nie do pokonania. Sam doktor nie wahał się padać na kolana przed ważnymi osobistościami, prosząc o łaskę dla cierpiących, całować rąk decydentów i apelować do ich chrześcijańskich sumień. Potrafił być uparty i stanowczy. Kiedy nie pomagały prośby, zasypywał urzędników petycjami, piętnującymi nadużycia strażników, wykazując pisemnie niewłaściwe praktyki stosowane przez nich wobec osób pozbawionych wolności. Znana jest opowieść o tym, jak Fiodor Piotrowicz sprze-

${ }^{16}$ Zob. А.Ф. Кони, Фёдор Петрович Гааз..., оp.cit., ss. 13-14.

${ }^{17}$ Zob. В. Варжапетян, 10 интересных фактов о докторе Гаазе, ор.cit.

${ }^{18}$ Zob. А.Ф. Кони, Фёдор Петрович Гааз..., ор.cit., s. 46.

${ }^{19}$ Zob. Аноним, ,Божий человек” доктор Гааз, ор.cit., ss. 34-38. 
ciwił się samemu metropolicie Filaretowi (Drozdowowi), który był zdania, że być może nie jest konieczne tak wielkie staranie o więźniów i skazańców, bo skoro ktoś został pozbawiony wolności, to na pewno nie jest bez winy i na karę zasłużył. Haass publicznie przypomniał hierarsze, że więźniem był także Chrystus ${ }^{20}$.

Heroiczny doktor zdawał sobie sprawę z tego, że człowiek uwięziony cierpi nie tylko w wymiarze cielesnym, ale także doświadczać może rozterek, które ranią go w sposób niematerialny. Cierpień przysparzało skazańcom bez wątpienia bezduszne rozdzielanie przez urzędników rodzin zmierzających na Syberię, odbieranie maleńkich dzieci matkom ${ }^{21}$, traktowanie na równi ludzi, którzy popełnili poważne przestępstwa kryminalne z tymi, którzy trafili na zesłanie z innych powodów. Haass przypominał władzom o irracjonalności takiego podejścia i częstokroć udawało mu się wybłagać dla kogoś litość albo połączyć rozdzielone rodziny ${ }^{22}$.

W roku 1825 Haass został naczelnym lekarzem Moskwy i rozpoczął starania o poprawę sytuacji chorych w szpitalach. Pod jego okiem instytucje te zaczęły się zmieniać: bardziej zadbano w nich o czystość, mniej było przypadków kradzieży, a lekarze zmuszeni byli solidniej poświęcać się swoim obowiązkom. Kontrola ze strony Haassa i jego wymagania nie podobały się niektórym osobom do tego stopnia, że zaczęto pisać na niego donosy do władz, oczerniając go i utrudniając mu życie. W takiej sytuacji doktor poprosił o zwolnienie go ze stanowiska i postanowił pozostać zwykłym lekarzem ${ }^{23}$. Zaangażowanie w pracę z wyłączeniem obowiązków funkcyjnych trwało krótko. Kiedy w 1829 roku powstał w Moskwie Komitet Opieki nad Więzieniami, doktor Haass został jego członkiem, a w latach 1830-1835 głównym lekarzem moskiewskich więzień, zajmując jednocześnie stanowisko sekretarza Komitetu ${ }^{24}$.

O ile stan rosyjskich szpitali na początku XIX wieku był opłakany, o tyle więzienia w Rosji były w tym czasie miejscem tragicznym. Zimne, wilgotne, przepełnione do granic możliwości cele mieściły ludzi skazanych za drobne przewinienia z ciężkimi przestępcami, prostytutki z kobietami tylko podejrzanymi o przestępstwo i czekającymi na wyrok, osoby stare z osobami młodymi, chore ze zdrowymi. Haass był zdania, że taka sytuacja przyczynia się zarówno do większej demoralizacji wśród więźniów, jak i błyskawicznego szerzenia się chorób. Niemoralne było także to, że

${ }^{20}$ Zob. А.Ф. Кони, Фёдор Петрович Гааз..., ор.cit., ss. 83-84.

${ }^{21}$ Już po śmierci Haassa okazało się, że wykupił on za własne pieniądze 74 chłopki pańszczyźniane i ich dzieci po to, by mogli towarzyszyć swoim bliskim, którzy zostali wysłani na katorgę. Zob. Л. Копелев, Святой доктор Федор Петрович, ор.cit., s. 196.

${ }^{22}$ Ibidem.

${ }^{23}$ Zob. C. Величко, Доктор Гааз: филантроп в волчей шубе, [w:] https://www.miloserdie. ru/article/kto-posadil-v-butyrke-topolya/ [dostęp: 20.05.2018].

${ }^{24}$ Zob. А.Ф. Кони, Фёдор Петрович Гааз..., op.cit., s. 33. 
brakowało w więzieniach ścisłego oddzielenia kobiet od mężczyzn. Problemem było też wyżywienie więźniów. Koszt dziennego wyżywienia więźnia określono na 15 kopiejek i sumę tę egzekwowano od aresztanta w momencie jego wypuszczania na wolność. Kiedy nie mógł on uregulować przypadającej na niego należności, trafiał z powrotem do więzienia jako niewypłacalny dłużnik. Brak funduszy na dzienną porcję żywności (pochodziły one często z datków) powodował, że niektórzy uwięzieni umierali z głodu. Państwo nie dawało także więźniom żadnej odzieży. Pozostawali więc w swojej, a kiedy ta się zniszczyła często byli niemal nadzy. Problem był także z obuwiem i ciepłymi kocami na wypadek zimna. Niektórych aresztantów przykuwano za szyję do ciężkich krzeseł, które musieli dźwigać ze sobą, kiedy chcieli się przemieścić. Stosowano też rozmaite metalowe okowy z ostrymi wystającymi elementami, które przymocowane do ciał uniemożliwiały więźniom położenie się spać ${ }^{25}$.

O ludzi uwięzionych w Rosji, jeszcze przed doktorem Friedrichem Haasem, upomniał się inny obcokrajowiec - Anglik John Howard (1726-1790). Reformowanie więzień rozpoczął w swoim kraju, gdzie apelował, by dyscyplina, jakiej poddawani są skazańcy miała rozumne granice, aby w procesie resocjalizacji ludzi odosobnionych szanować ich człowieczeństwo oraz zwracać uwagę na ich religijno-moralne wychowanie. Zalecał wychowywanie więźniów przez pracę. Swoje idee Howard szerzył w całej Europie, ale największy skutek odniosły one w systemie penitencjarnym w Ameryce. W 1781 roku Howard przybył do Rosji. Zaproszony na salony przez Katarzynę II - odmówił carycy, twierdząc, że celem jego przyjazdu jest odwiedzanie więzień, a nie pałaców. W czasach Katarzyny Rosja była jedynym krajem w Europie, który zrezygnował z kary śmierci. Howard z niedowierzeniem odnosił się do tego faktu. Wnikliwe obserwacje rosyjskiego systemu kar doprowadziły Anglika do wniosku, że kara knuta jest bardzo brutalna, a zastosowana w dużej intensywności odnosi dokładnie taki sam skutek jak kara śmierci. Knut dla Howarda był zakamuflowaną formą tej ostatniej. Dzięki temu angielskiemu działaczowi społecznemu także w Rosji zaczęto mówić o uczynieniu warunków panujących w więzieniach bardziej humanitarnymi, o konieczności odróżnienia kary za przestępstwo od męki za popełnione winy ${ }^{26}$.

Mimo że John Howard zasiał dobre ziarno w dziedzinie ulepszenia systemu penitencjarnego w Rosji, od końca wieku osiemnastego aż do początku wieku dziewiętnastego niewiele formalnie dla więźniów w Rosji się zmieniło. Dopiero w czasach

${ }^{25}$ Zob. А.Ф. Кони, Федор Петрович Гааз..., ор.cit., ss. 7-10.

${ }^{26}$ Zob. A.Е. Яновский, Говард Джсн, [w:] Энциклопедический словарь Брогкауза и Эфорна в 89-ти томах, t. IX, Санкт-Петербург 1893, ss. 7-9; А.Ф. Кони, Федор Петрович Гааз..., ор.cit., 2006. 
Aleksandra I, w roku 1819, pod wpływem kolejnego zagranicznego filantropa Waltera Wenninga powstał w Petersburgu Komitet Opieki nad Więzieniami. Jego członkami mogły zostać osoby, które gotowe były przeznaczać środki na poprawę sytuacji więźniów i więźniarek ${ }^{27}$. Do czasu powstania podobnego Komitetu w Moskwie upłynęło zatem aż dziesięć lat.

Praca w Komitecie Opieki nad Więzieniami stała się zwrotnym punktem w życiu doktora Fiodora Piotrowicza Haassa. Mógł już nie tylko jako osoba prywatna, ale także z „urzędu” wstawiać się przed władzami za aresztantów, co w oczach rosyjskiej biurokracji przydawało nieco większej niż wcześniej wagi jego inicjatywom. W ślad za sprawowaną funkcją nie pojawiły się jednak u Haassa żadne dodatkowe fundusze, które mogłyby stanowić podstawę dla realizacji jego pomysłów, dlatego, podobnie jak wcześniej, doktor wykorzystywał w swojej pracy głównie własne środki. To za nie w 1832 roku stworzył szpital dla aresztantów w przejściowym więzieniu na Worobiowych Wzgórzach, a w 1836 roku przy tymże więzieniu Hass otworzył szkołę dla dzieci więźniów. Zbudował także cerkiew, w której zesłańcy mogli się modlić i spowiadać. W 1833 roku, również z własnych funduszy, Fiodor Piotrowicz częściowo przebudował moskiewski zamek więzienny (obecnie znajduje się w nim Więzienie Butyrskie), budując podłogi z desek (wcześniej więźniowie leżeli na gołej ziemi), piętrowe prycze, toalety, umywalki, otwierające się okna i po raz pierwszy wprowadził regularne wyżywienie dla uwięzionych. Kolejnym ważnym osiagnięciem Haassa było otwarcie w Moskwie Szpitala Policyjnego dla najbiedniejszych i bezdomnych ${ }^{28}$. Za życia doktora przez szpital przeszło ponad 30000 chorych. Byli to głównie ludzie znalezieni na moskiewskich ulicach z odmrożeniami, głodni, poranieni, potrąceni przez karety, a także ludzie bezdomni ${ }^{29}$. Haass nigdy nie żałował własnych środków tam, gdzie mowa była o potrzebujących. Nic więc dziwnego, że jego pokaźny majątek bardzo szybko zaczął topnieć. Sam doktor nie przywiązywał wagi do gromadzonych funduszy, nie dbał też o to, by wydawać je na swoje wygody. Doszło do tego, że przez całe lata pojawiał się w znoszonym płaszczu i starym przetartym fraku, od którego wzięło się kolejne określenie, którym charakteryzowano tego wielkiego filantropa „Don Kichot w zniszczonym fraku” ${ }^{30}$. W ciągu 24 lat pracy w Komitecie Opieki nad Więzieniami, czyli od roku 1829 aż do śmierci, doktor na 253 zebrania Komitetu opuścił tylko jedno z powodu choroby ${ }^{31}$.

${ }_{27}$ Zob. А.П. Керзум, Общество попечительное о тюрьмах, [w:] http://encblago.lfond.spb. ru/showObject.do?object=2823335121 [dostęp: 20.05.2018].

${ }^{28}$ Zob. B. Варжапетян, 10 интересных фактов о докторе Гаазе, ор.cit.

${ }^{29}$ Zob. В. Лебедева, Спешите делать добро, „Христианская газета «Для Тебя»” 2002, nr 56, [w:] http://www.foru.ru/article.159.html [dostęp: 20.05.2018].

30 Л. Копелев, Святой доктор Федор Петрович, op.cit., ss. 131, 203.

${ }^{31}$ Zob. Н.Э. Вашкау, „, Святой доктор” Федор Петрович Гааз, op.cit. 
Friedrich Haass żywił głębokie przekonanie, że istnieje ścisły związek między nieszczęściem, przestępstwem i chorobą, dlatego dużą wagę przywiązywał do dbałości o moralność aresztantów, zależało mu na ich duchowej odnowie i niewracania na drogę przestępczą. Napisał dla nich nawet książeczkę zatytułowaną $A B C$ chrześsijańskiej przykładności (А Б В христианского благонравия) i rozdawał ją ludziom udającym się na zesłanie. Żeby jej noszenie nie przeszkadzało w drodze Haass umieszczał poszczególne egzemplarze w specjalnie przygotowanych woreczkach przystosowanych do zawieszenia na szyi. $A B C$ mówiło o potrzebie unikania złych skłonności i pracy nad sobą, a także o dbałości o dusze innych. Na końcu książeczki było zobowiązanie do starania się o wcielanie $\mathrm{w}$ życie podanych zasad i miejsce na podpis skazańca. Umiejący czytać i pisać mogli umieścić tam swoje imię i nazwisko, zaś analfabeci trzy krzyżyki. Anatolij Koni, pierwszy biograf doktora Haassa, uważa, że ta właśnie inicjatywa doktora świadczy o jego wzruszającej wierze „w lepsze strony natury ludzkiej [...] i odrodzenie człowieka"32.

Fiodor Piotrowicz widział bardzo wiele ludzkich nieszczęść w czasie, gdy opiekował się chorymi, przestępcami, więźniami i miał ogrom zrozumienia dla słabości człowieka. Zdawał sobie sprawę z tego, że są ludzie, o których Chrystus mówił, iż „nie wiedza, co czynią” i twierdził, że za nich trzeba się bardzo gorąco modlić. Swoich podopiecznych Haass postrzegał jako tych, którzy pozbawieni są rozeznania między dobrem i złem, za istoty, za które trzeba się wstawiać zarówno na ziemi, jak i w niebie.

„Gdyby szatan mógł się modlić, nie byłby szatanem” - pisał Haass w innej swojej książeczce pod tytułem Wezwanie do kobiet (Appel aux femmes) $)^{33}$. Pozycja ta ukazała się najpierw po francusku. Przetłumaczono ją i wydano w Rosji dopiero po śmierci Haassa. Jest to utwór o tyle ważny, że pokazuje szerokość horyzontów myślenia doktora, jego dalekowzroczność, ale także doskonale oddaje jego filozofię życiową. Warto zatem przyjrzeć się bliżej tej pracy. Haass wyraża w niej przekonanie, że ze złem należy walczyć na bardzo wczesnych etapach życia człowieka, a szczególna rola na tym polu należy do kobiet - matek, żon, sióstr, które nie mają stanowić jedynie dodatku do swojego syna, męża czy brata, ale powinny wykazywać się samodzielnością myślenia i działania. Muszą one stwarzać warunki, w których rodzić się będzie dobro. Haass zachęca kobiety, by były centrum ogniska domowego, dbając przede wszystkim o duchową stronę domostwa i nie przykładały wielkiej wagi do blichtru codzienności i pustych rozrywek. Namawia je, aby zajmowały się dobroczynnością i nie traciły danego im czasu na sprawy nieistotne dla życia. „Droga

${ }^{32}$ А.Ф. Кони, Федор Петрович Гааз..., ор.cit., s. 92.

${ }^{33}$ Ф.П. Гааз, Призыв к женщинам. Посмертное издание, Москва, Типография И.И. Кушнерева, 1897. 
prowadząca do Królestwa Bożego jest wąska i trudna dla ludzi świeckich"34 - przestrzega doktor i przypomina jednocześnie, że żadne doczesne radości nie są warte tego, by zapominać o wartościach wyższych, które mogą uszlachetniać i przynosić wieczny pożytek. Kobiety powinny być miłosierne, wystrzegać się samolubstwa i starać się pomagać bliźnim, dawać jałmużnę. „Naszą prawdziwą własnością pozostaje tylko to, co możemy rozdać biednym i to, co tracimy na sprawy dobroczynności” (s. 42) nauczał kobiety Haass i stawiał przed nimi konkretne zadania:

„Kobiety chrześcijanki będą czynnie pomagać w organizowaniu sierocińców dla potrzebujących, dla biednych i chorych, dla sierot i starców, opuszczonych i nie mających siły zapracować na chleb. Nie będą nigdy odkładać do jutra tego, co powinny zrobić dzisiaj. Będą śpieszyć się czynić dobro. A o to, czego nie będą mogły zrobić same, będą prosić tych, którzy będą w stanie to uczynić. Nie będą wstydzić się i bać upokorzenia i nie zatrzyma ich odmowa, a ich działanie zamieni się w drogocenną perłę" (s. 15-16).

Kobiety powinny być wychowawczyniami nowych pokoleń, starać się przestrzegać zasad chrześcijańskich i tępić największe wady społeczne, do których Haass zalicza: obmowę, nadużywanie alkoholu, skłonność do kłótni i grzeszne związki. Kobiety powinny pracować nad samodoskonaleniem, wykazywać współczucie i zrozumienie dla osób, które im służąi sąod nich w jakikolwiek sposóbzależne. Domowników mają starać się zachęcać do właściwej lektury oraz zachowania dnia świątecznego (s. 12-14). W końcu rola osób płci żeńskiej polegać ma także na tym, by pobudzać innych do uczynków miłosierdzia zarówno wobec ludzi biednych, jak i osób, którym obcy jest Chrystus. Nie ulega wątpliwości, że Haass ma tutaj na myśli przeznaczanie środków na pomoc dla więźniów i skazańców. Uważa on, że każdy jest w stanie zaoszczędzić choćby niewielką sumę, która potem może stać się jałmużną (s. 56-57). Powołując się na świętego Łukasza, doktor zachęca: „Sprzedawajcie majątki wasze i dawajcie jałmużnę, [...] bo tam będzie skarb twój, gdzie serce twoje" (s. 43). W innym miejscu mówi, że w uczynkach miłosierdzia nie zawsze chodzi o sprawy znaczące i spektakularne:

„Jeśli ktoś nie może okazywać swojej miłości w sprawach wielkich, niech przejawia ją przynajmniej w małych: niech ugasi pragnienie miską świeżej wody, pomoże przyjacielskim słowem pociechy, pouczenia, współczucia temu, kto cierpi smutek i znajduje się w trudnym położeniu, niech godzi ludzi, którzy się pokłócili lub rozeszli i przekonuje, by żyli w pokoju" (s. 46).

\footnotetext{
${ }^{34}$ Ibidem, s. 38. Dalej podaję strony bezpośrednio w artykule, powołując się na to wydanie.
} 
Doktor Fiodor Piotrowicz parafrazuje także List do Tesaloniczan przypominając: „Patrzcie, aby nikt drugiemu nie odpłacał złem za zło i zawsze szukajcie dobra w sobie i u innych" (s. 14). Bardzo ciekawa jest przy tym myśl Haassa o tym, że ludzi, którzy znaleźli się na złej drodze nie należy karcić i nauczać zbyt ostrym słowem, gdyż nie przyczynia się ono do ich poprawy, a jedynie rozdrażnia i powoduje nieufność. Doktor mówi i o tym, że człowiek nie powinien zbyt prędko ferować wyroków wobec innych i zbyt surowo ich osądzać. „Nie sądź, a nie będziesz sądzony" przywołuje swoim czytelnikom słowa ewangelisty Fiodor Piotrowicz. Najważniejsze wydaje mu się to, że należy czynić bliźnim dobro na wszelki możliwy sposób. Właśnie wezwanie „Śpieszcie się czynić dobro” okazuje się maksymą życia Haassa $^{35}$.

Bezgraniczne poświęcenie doktora dla sprawy jego podopiecznych, bezkompromisowość i upór w zwalczaniu przeciwności zaczęły zachęcać do podążania jego śladem także innych arystokratów. Wśród nich była księżna Natalia Borysowna Szachowska (1825-1906), która pod wpływem Haassa została siostrą miłosierdzia. Porzuciła swoje pałace, aby zamieszkać przy Szpitalu Policyjnym i móc poświęcić jak najwięcej czasu chorym. A wybór jej nie był przypadkowy, bowiem lekarzem i przyjacielem jej rodziny - Światopołk-Czetwiertyńskich - był właśnie Fiodor Piotrowicz Haass, którego księżna Szachowska nazwała swoim duchowym mentorem i pod jego kierunkiem w tymże szpitalu uczyła się opieki nad chorymi. Już po roku Natalia Borysowna stanęła na czele grupy składającej się z 30 sióstr miłosierdzia, a w 1864 roku utworzyła Wspólnotę Sióstr Miłosierdzia Matki Boskiej Nieustającej Ротосу (Утоли моя печали). Ze swoich osobistych środków wraz z siostrami stworzyła w szpitalu miejsca dla 200 chorych, sierociniec, zorganizowała jedną z pierwszych szkół sióstr miłosierdzia. Siostry pracowały nie tylko w Moskwie, ale także w Twerze, Kursku, Sankt-Petersburgu oraz w leprozorium w Irkucku. Z czasem liczba sióstr we wspólnocie dosięgła stu ${ }^{36}$.

Pojawili się także inni następcy doktora Haassa. W Szpitalu Policyjnym przyjmującym nagłe przypadki i udzielającym bezpłatnej pomocy osobom z odmrożeniami, bezdomnym, potrąconym przez konie na ulicy, a także głodnym, przebywał żydowski chłopiec przybyły z Litwy z grupą sierot ${ }^{37}$. „Święty doktor” otoczył go szczególną opieką i stał się również jego mentorem. Chłopiec został ochrzczony i nadano mu

${ }^{35}$ Zob. А.Ф. Кони, Фёдор Петрович Гааз..., ор.cit., s. 33.

${ }^{36}$ Zob. Коллектив авторов, Община сестёр милосердия „, Утоли моя печали”, [w:] https://fil. wikireading.ru/57270 [dostęp: 20.05.2018].

${ }^{37}$ Zob. Е.В. Харламов, Последователи святого доктора Гааза, [w:] Е.В. Харламов, Е.К. Склярова, О.Ф. Киселева, Долг врача и гражданина, Ростов-на-Дону: Мини Тайп, 2018, s. 22. 
imię Mikołaj. Po wyleczeniu rozpoczął naukę pod kierunkiem swojego opiekuna, zajmując się chorymi. Z czasem Mikołaj Norszyn wstapił na wydział medyczny Imperatorskiego Uniwersytetu Moskiewskiego. Fiodor Pietrowicz Haass śledził najpierw sam proces nauczania swego wychowanka, a potem pracę, którą ten zaczął wykonywać w Riazaniu. Jako lekarz Norszyn wykazywał się rzetelną wiedzą medyczną, wzbudzając szacunek innych lekarzy. Zawsze też był gotów nieść pomoc ludziom biednym i opuszczonym. O Hassie, lekarzu-humaniście, mówiono, że nigdy nie odmawia pomocy. „У Гааза нет отказа” (Haass nie odmawia) powtarzano w dziewiętnastowiecznej Moskwie. W jednym z listów do Norszyna Fiodor Piotrowicz pisał:

„Najpewniejszą drogą do szczęścia nie jest pragnienie bycia szczęśliwym, ale czynienie innych szczęśliwymi. Dlatego należy skupiać uwagę na potrzebach innych, troszczyć się o nich, nie bać się pracy, wspomagać ich radą i uczynkiem, jednym słowem, kochać drugiego człowieka" ${ }^{38}$.

Haass doczekał się za swoją działalność nagród. Otrzymał Order Św. Włodzimierza Czwartego Stopnia oraz rangę radcy nadwornego ${ }^{39}$.

Postawa życiowa doktora Fiodora Piotrowicza budziła także podziw rosyjskiej arystokracji i ludzi pióra. Wśród piszących o Haassie byli Aleksander Turgieniew, Fiodor Dostojewski, Antoni Czechow, Maksym Gorki, Lew Kopielew czy Wardwan Warżapetian.

Wzmianki o niezwykłej postaci doktora znajdujemy w listach Aleksandra Turgieniewa do księcia Piotra Wiaziemskiego od 1816 roku. Najpierw jest w nich mowa o powstaniu towarzystwa, które stawia sobie za cel dążenie do poprawy położenia więźniów ${ }^{40}$, potem Turgieniew pisze też o samym Haassie. Doktor imponuje mu tym, że jest uczniem Schellinga oraz niezwykle miłosiernym podejściem do potrzebujących. Fascynacja Turgieniewa Haassem musiała być duża, bo i on zaangażował się w pomoc zesłańcom na Worobiowych Wzgórzach. Pisze o tym w liście z 21 lipca 1836 roku:

„Wczoraj spędziłem poranek na Worobiowych Wzgórzach, w więzieniu, z którego odsyłają na Syberię. Widziałem łańcuchy i łzy, ale i duch chrześcijańskiego miłosierdzia w doktorze Haassie, któremu jestem wdzięczny za wzruszające i zbawienne dla duszy pouczenie. A Haass jest uczniem Schellinga [...]"41.

${ }^{38}$ Cуt. za: А.Ф. Кони, Фёдор Петрович Гааз..., op.cit., s. 128

${ }^{39}$ Zob. Н.Э. Вашкау „Святой доктор” Федор Петрович Гааз, ор.cit., s. 27.

${ }^{40}$ Zob. Переписка князя П. А. Вяземского с А. И. Тургеневым. 1812-1819, [w:] Остафьевский архив князей Вяземских, t. 1, red. В.И. Саитов, Санкт-Петербург, Изд. С.Д. Шереметьева, 1899, s. 206.

${ }^{41}$ Переписка князя П. А. Вяземского с А. И. Тургеневым. 1824-1836, [w:] Остафьевский архив князей Вяземских, t. 3, red. В.И. Саитов, Санкт-Петербург, Изд. С.Д. Шереметьева, 1899, s. 337. 
Trudno na podstawie korespondencji wyrokować, w jakim zakresie jej autor włączał się w działalność Haassa. Wiele wskazuje na to, że zainteresowanie losami zesłańców i pracą niemieckiego doktora towarzyszyło Turgieniewowi przez kilka lat. Prawdopodobnie bywał on na Worobiowych Wzgórzach jeszcze w 1842 roku. Pomaganie przypominało jednak w jego przypadku bardziej kaprys niż regularną pracę. Potwierdza to jeden z listów Turgieniewa do Wiaziemskiego datowany 31 października wspomnianego roku, w którym mowa jest o skali potrzeb, które trzeba zaspokoić podczas transportowania zesłańców przez Moskwę oraz o tym, że autor listu, wstydzi się tego, że przyjmując na siebie rolę pomocnika Haassa nie wykazuje systematyczności i gorliwości w pracy z potrzebującymi:

„Jeśli byłoby nawet jeszcze dziesięciu Haasów, to nie starczyłoby ich dla samych Worobiowych Wzgórz w niedzielę. On, Haas, jeszcze niedawno uratował dwie rodziny; mnie nic się nie udaje. Wiesz, co męczyło mnie tego dnia, kiedy dostałem Twoje listy? Ja dwie niedziele z lenistwa i z powodu bólu w nodze nie byłem na Worobiowych Wzgórzach i moich protegés, [...] wywieziono na Syberię, a im na jedzenie, szczególnie z dziećmi, [...] a dzieci mają dużo [...], nie starczy do Włodzimierza" ${ }^{\text {"42 }}$.

Fiodor Dostojewski włączył historię o dobroczynnej działalności doktora Haassa do powieści Idiota, ukrywając jednak jego prawdziwą tożsamość pod postacią ,staruszka generała":

„W Moskwie mieszkał pewien starzec, pewien 'generał', to znaczy rzeczywisty radca stanu o niemieckim nazwisku; całe życie włóczył się po więzieniach i rozmawiał z przestępcami; każda partia zesłańców idąca na Sybir wiedziała już, że na Wzgórzach Worobiowych odwiedzi ją 'staruszek generał'. Spełniał swoje czynności nadzwyczaj poważnie i nabożnie; zjawiał się, chodził pomiędzy szeregami zesłańców, którzy go otaczali, zatrzymywał się przed każdym, każdego wypytywał o jego potrzeby, nauk moralnych nie udzielał prawie nikomu, nazywał ich wszystkich pieszczotliwie „kochanymi chłopaczkami”. Dawał im pieniądze, przysyłał niezbędne rzeczy - onuce, owijacze, płótno, przynosił czasem nabożne książeczki i rozdawał umiejącym czytać, w zupełnym przekonaniu, że oni będa je czytali w drodze i ten, co umie czytać, przeczyta temu, co nie umie. O przestępstwa rzadko pytał, co najwyżej słuchał, gdy przestępca zaczynał mówić. Wszystkich przestępców traktował jednakowo, różnicy między nimi nie robił. Rozmawiał z nimi jak z braćmi, a i oni zaczęli go wreszcie uważać za ojca [...]. Tak czynił przez wiele lat, do samej śmierci; doszło do tego, że znali go ludzie w całej Rosji i na całej Syberii, to znaczy wszyscy przestępcy"43.

42 Переписка князя П. А. Вяземского с А. И. Тургеневым. 1837-1845, [w:] Остафьевский архив князей Вяземских, t. 4, red. В.И. Саитов, Санкт-Петербург, Изд. С.Д. Шереметьева, 1899, s. 186.

${ }^{43}$ F. Dostojewski, Idiota, tłum. J. Jędrzejewicz, Warszawa, Państwowy Instytut Wydawniczy, 1961, ss. 449-450. 
Antoni Czechow opublikował w 1894 roku, w czasopiśmie „Русские Ведомости", Opowiadanie starszego ogrodnika (Рассказ старшего садовника). Роglądy tytułowego bohatera na kwestie winy i kary są bardzo zbliżone do przekonań doktora Haassa. Uważa on bowiem, że człowiek jest z natury dobry i skłania się bardziej ku utożsamionej z dobrem prawdzie niż złu. Na potwierdzenie swoich teorii ogrodnik opowiada historię znaną mu z ustnych opowiadań pewnego doktora Thomsona lub Willsona, który niektórymi cechami przypomina Haassa: jest obcokrajowcem, żyjącym bardzo skromnie niczym mnich, wiele czasu poświęca na kontemplację, jest świetnym znawcą swojej profesji, leczy bardzo skutecznie, ma wielkie serce. Lekarz ten, choć sam bywał słaby, nigdy nie odmawiał pomocy potrzebującym, gdyż najzwyczajniej kochał ludzi i poświęcał się dla nich: „Za nic miał upał i zimno, gardził głodem i pragnieniem. Pieniędzy nie brał, a co dziwne, kiedy umierał jakiś jego pacjent, to doktor szedł za trumną pacjenta wraz z krewnymi zmarłego" ${ }^{44}$. Z kolei Maksym Gorki przekonywał, że: „O Haassie powinno się czytać wszędzie, o nim wszyscy powinni wiedzieć, gdyż jest nawet bardziej święty niż Teodozjusz Czernihowski" ${ }^{45}$.

Współcześnie Haass pojawia się w opowiadaniu Wardwana Warżapetiana Trzynasta pasja (Тринадиатая страсть). Narrator, przedstawiający się jednocześnie jako współpracownik doktora Haassa - Arsjenij Pustoszyn mówi o doktorze jako o człowieku, do miłosierdzia którego zwracano się w setkach listów, jakie otrzymywał, jak do ostatniej nadziei na ziemi, o tym, że Haassa błogosławiła cała katorżnicza Rosja, a wszyscy nieszczęśnicy widzieli w nim wybawiciela. Pustoszyn powołuje się na Charlesa Fouriera francuskiego utopistę-socjalistę, który podzielił wszystkie namiętności rządzące postępkami ludzi na 12 kategorii, zaś jako szczególną poza nimi wyodrębnił trzynastą pasję - harmonię. Twierdził on, że ludzie charakteryzujący się nią nie są zdolni pogodzić się z tym, co jest przez wszystkich powszechnie uznawane i bez względu na okoliczności dążą do pogodzenia swego szczęścia ze szczęściem całej ludzkości. Takie cechy Fourier przypisywał reformatorom, a także rewolucjonistom. Pustoszyn stwierdzał, że Haass bezwarunkowo zaliczał się do takich indywidualności, które miały wykształcony zmysł harmonii ${ }^{46}$. Otrzymał on egzemplarz książki od Hassa, opowiadającej o podróżach doktora na Kaukaz i jego odkryciach źródeł mineralnych z dedykacją: „Drogi Arsieniju Iljiczu, niech Pan nie osądza ludzkich win, a będzie Pan szczęśliwym człowiekiem" "47. Haass w swej działalności na rzecz człowieka, a tym samym dla dobra ludzkości stawał się przewodnikiem i zarazem

${ }^{44}$ А.П. Чехов, Рассказ старшего садовника, [w:] http://chehov.niv.ru/chehov/text/rasskaz-starshego-sadovnika.htm [dostęp: 20.05.2018].

${ }^{45}$ В. Варжапетян, Доктор Гааз, Москва, Издательство Францисканцев, 2018, [w:] https:// 7books.ru/vardvan-varzhapetyan-doktor-gaaz/ [dostęp: 20.05.2018], s. 13.

${ }^{46}$ Zob. B.B. Варжапетян, Тринадияатая страсть, Москва, Современник, 1988, s. 109.

${ }^{47}$ Tamże, s. 106. 
duszpasterzem wnoszącym hasła propagujące cnoty chrześcijańskie, które zespalając się tworzyły harmonię, spokój wewnętrzny, duchowe przebudzenie człowieka. Pustoszyn, zestawiając Haassa z Fourierem dokonał pewnego rodzaju nadużycia. Być może, będąc pod wielkim wrażeniem czynów „świętego” lekarza i wielkiego społecznika w jednym, widział w nim człowieka dokonującego wielkich zmian. A ponieważ dokonywała się rewolucja dusz, sumień ludzkich, ale tylko w pozytywnym znaczeniu, nacechowana wszelkim dobrem i miłością chrześcijańską mogła być rozpatrywana jako wielkie ,poruszenie” serc ludzkich.

Postawa życiowa Haassa zachwyciła współcześnie także Lwa Kopielewa, który mając za sobą doświadczenie więzienia i zesłania podkreślał, jak bardzo ważne jest przypominanie jego zasług dla skazańców i osób cierpiących w przymusowym odosobnieniu. Zauważał przy tym, iż powtórzenie wyczynu doktora Haassa może być dane jedynie nielicznym ${ }^{48}$.

Niedawno postać doktora Haassa pojawiła się także w polskim opracowaniu Szymona Hołowni Święci pierwszego kontaktu, w której autor poświęcił mu cały rozdział, pisząc o nim: „Od razu ujmuje w tym człowieku to, że zamiast mękolić, jaki system jest beznadziejny, wszedł w sam środek tej beznadziei i próbował zmienić ją od środka. Na ile się da, w mikroskali, na miaręjednego człowieka"49. Rzeczywiście Haass postępował z chorymi w sposób daleko odbiegający od standardów jego czasów. I nie chodzi tu tylko o bezpłatne leczenie biednych. Doktor nie bał się żadnych epidemii ani chorób zakaźnych. Przytulał i całował chorych. Nie brzydził się psujących się pod wpływem choroby ciał. Zawsze znajdował ciepłe słowo dla podopiecznych, a nawet czas na czytanie bajek umierającym dzieciom ${ }^{50}$.

Postawa Haassa to przykład heroizmu ponad podziałami religijnymi i przywiązaniem do własnej tradycji kulturowej. Haass - niemiecki katolik, niosący pomoc zesłańcom i ludziom z marginesu społecznego należącym do różnych wyznań i narodowości oraz prezentujący im uniwersalne wartości chrześcijańskie jako warunek ich odkupienia, jest fenomenem, który nie miał sobie równego w wieku dziewiętnastym.

Friedrich Haass zmarł w Moskwie w 1853 roku. Z jego wielkiego majątku nie pozostało nic, bo wszystko rozdał potrzebującym. W jego mieszkaniu znajdującym się przy Szpitalu Policyjnym z rzeczy cennych znaleziono kilka teleskopów. Podobno Haass zmęczony za dnia widokiem bezmiaru ludzkiego cierpienia lubił nocami obserwować gwiazdy ${ }^{51}$.

${ }^{48}$ Zob. Л. Копелев, Святой доктор Федор Петрович, ор.cit., s. 214.

${ }^{49}$ S. Hołownia, Stuga Boży Friedrich Joseph Haas (1780-1853), [w:] idem, Święci pierwszego kontaktu, Kraków, Znak, 2017, s. 229.

${ }^{50}$ Zob. В. Лебедева, Спешите делать добро, ор.cit.

${ }^{51}$ Zob. C. Вознесенский, Добрый доктор Гааз, „Москва. Журнал русской культуры” 2004, nr 12, [w:] http://www.moskvam.ru/2004/12/voznesensky.htm [dostęp: 20.05.2018]. 
Doktor został pochowany w Moskwie na cmentarzu Wwiedieńskim na koszt państwa. W pogrzebie miało uczestniczyć około 20 tysięcy żałobników. Do miejsca wiecznego spoczynku odprowadzały Fiodora Piotrowicza osoby tak znane jak Iwan Kieriejewski, Jurij Samarin, Piotr Czaadajew, ministrowie, oberprokurator, oberpolicmajster. „Takiego pochodu nie było nawet na pogrzebie Gogola”, zakrzyknie, wspominany już wcześniej Warżapetian ${ }^{52}$.

Na grobie heroicznego doktora umieszczono wielki kamień, a na nim postawiono krzyż. Na kamieniu znajduje się napis „Śpieszcie się czynić dobro!” („Спешите делать добро!'), zawołanie doktora, któremu do końca życia pozostał wierny. W roku 1909 doktorowi Haassowi postawiono pomnik ze zbiórek pieniędzy od mieszkańców Moskwy, autor pomnika nie wziął wynagrodzenia za jego wykonanie.

W 1999 roku, dzięki inicjatywie ówczesnego nuncjusza papieskiego w Moskwie, arcybiskupa Tadeusza Kondrusiewicza, rozpoczęło się zbieranie i opracowywanie materiałów do procesu beatyfikacyjnego ${ }^{53}$. W sierpniu 2017 roku imieniem tego filantropa została nazwana jedna z ulic Moskwy znajdująca się w pobliżu ambasady Niemiec, zaś 6 maja 2018 roku Kościół katolicki ogłosił Friedricha Josepha Haassa błogosławionym ${ }^{54}$.

\section{Literatura}

Dostojewski F., Idiota, thum. J. Jędrzejewicz, Warszawa, Państwowy Instytut Wydawniczy, 1961.

Hołownia S., Stuga Boży Friedrich Joseph Haas (1780-1853), [w:] idem, Święci pierwszego kontaktu, Kraków, Znak, 2017.

Przełomiec M., Święty doktor z Moskwy, „Przewodnik Katolicki”, [w:] https://www. przewodnik-[katolicki.pl/Archiwum/2016/Przewodnik-Katolicki-8-2016/ Wiara-i-Kosciol/Swiety-doktor-z-Moskwy [dostęp: 20.05.2018].

Wollensak G., Friedrich Josef Haas- der heilige Doktor von Moskau, „Klinische Monatsblatter fur Augenheilkunde“, 2005, nr 222, ss. 513-515.

${ }^{52}$ B.В. Варжапетян, Тринадцатая страсть, ор.cit., s. 78.

${ }^{53}$ Zob. M. Przełomiec, Święty doktor z Moskwy, „Przewodnik Katolicki”, [w:] https://www.przewodnik-[katolicki.pl/Archiwum/2016/Przewodnik-Katolicki-8-2016/Wiara-i-Kosciol/Swiety-doktorz-Moskwy [dostęp: 20.05.2018].

${ }^{54}$ Zob. Католическая иерковь причислила доктора Гааза клику блаженных, [w:] https:// www.miloserdie.ru/news/katolicheskaya-tserkov-prichislila-doktora-gaaza-k-liku-blazhennyh/ [dostęp: 20.05.2018]. 
Аноним, „Божий человек” доктор Гааз, „Истина и жизнь” 1992, nr 4, ss. 34-38. Варжапетян В., 10 интересных фактов о докторе Гаазе, [w:] http://xn--80aqecdrlilg.xn--p1ai/)/doktor-gaaz / [dostęp:10.05.2018].

Варжапетян В., Доктор Гааз, Москва, Издательство Францисканцев, 2018, [w:] https://7books.ru/vardvan-varzhapetyan-doktor-gaaz/ [dostęp: 20.05.2018].

Варжапетян В.В., Тринадияатая страсть, Москва, Современник, 1988.

Вашкау Н.Э., „, Сятой доктор” Федор Петрович Гааз, „Вестник Волгоградского государственного университета. Серия 4. История” 2012, nr 2 (22), ss. 26-31.

Величко С., Доктор Гааз: филантроп в волчей шубе, [w:] https://www.miloserdie.ru/article/kto-posadil-v-butyrke-topolya/ [dostęp: 20.05.2018].

Вознесенский С.А., Добрый доктор Гааз, „Москва. Журнал русской культуры” 2004, nr 12, ss. 212-218.

Гааз Ф.П., Призыв к женщинам. Посмертное издание, Москва, Типография И.И. Кушнерева, 1897.

Грандо А., Федор Гааз: Счастье - делать счастливым других, „Медицинская газета" 1977, nr 61, s. 11.

Каликинская Е., Тюремный доктор Гааз: безумный филантроп и помощник осужденных, „Аргументы и факты” 2013, nr 45, [w:] http://www.aif.ru/society/history/1017397 [dostęp: 20.05.2018].

Католическая ичерковь причислила доктора Гааза к лику блаженных, [w:] https://www.miloserdie.ru/news/katolicheskaya-tserkov-prichislila-doktoragaaza-k-liku-blazhennyh/ [dostęp: 20.05.2018].

Керзум А.П., Общество попечительное о тюрьмах, [w:] http://encblago.lfond. spb.ru/showObject.do?object=2823335121 [dostęp: 20.05.2018].

Коллектив авторов, Община сестёр милосердия „Утоли моя печали”, [w:] https://fil.wikireading.ru/57270 [dostęp: 20.05.2018].

Кони А.Ф., Федор Петрович Гааз. Библиографический очерк, Москва, Сестричество во имя преподобномученицы великой княгини Елизаветы, 2006, 240 ss.

Копелев Л., Святой доктор Федор Петрович, Москва, Центр книги Рудомино, 2013.

Лебедева В., Спешите делать добро, „Христианская газета «Для Тебя»” 2002, nr 56, [w:] http://www.foru.ru/article.159.html [dostęp: 20.05.2018].

Мессель М.А., Из истории скорой медицинской помощи в России, „Советское здравохранение" 1960, nr 9, ss. 53-58.

Московский очаг милосердия. Святой доктор Гааз. Сборник к 230 -летию со дня рождения Ф.П.Гааза, Москва, Издательство дом Тончу, 2010, 444 ss.

Мурзина М., „, У Гааза нет отказа”. Знаменитый столичный доктор излечивал всех, „Аргументы и факты” 2014, nr 19, [w:] http://www.aif.ru/society/hi- 
story/u_gaaza_net_otkaza_znamenityy_stolichnyy_doktor_izlechival_vseh [dostęp 20.05.2018].

Переписка князя П. А. Вяземского с А. И. Тургеневым. 1812-1819, [w:] Остафьевский архив князей Вяземских, t. 1, red. В.И. Саитова, Санкт-Петербург, Изд. С.Д. Шереметьева, 1899.

Переписка князя П. А. Вяземского с А. И. Тургеневым. 1824-1836, [w:] Oстафьевский архив князей Вяземских, t. 3, red. В.И. Саитов, Санкт-Петербург, Изд. С.Д. Шереметьева, 1899.

Переписка князя П. А. Вяземского с А. И. Тургеневым. 1837-1845, [w:] Остафьевский архив князей Вяземских, t. 4, red. В.И. Саитов, Санкт-Петербург, Изд. С.Д. Шереметьева, 1899.

Петров Г., Ф.П. Гааз. Друг обездоленных, Москва, Сытин, 1902, 36 ss.

Сосницкий А. „Добрый доктор”, „друг несчастных” Федор Петрович Гааз, Москва, Оксаковская, 1900, $64 \mathrm{s.}$

Феофанов Ю., „Тюремный доктор” Федор Петрович Гааз, „Российская Федерация сегодня: Общественно-политический журнал Федерального собрания парлямента РФН” 2007, nr 22, ss. 58-59.

Харламов Е.В., Последователи святого доктора Гааза, [w:] Е.В. Харламов,

Е.К. Склярова, О.Ф. Киселева, Долг врача и гражданина, Ростов-на-Дону: Мини Тайп, 2018, 215 ss.

Чехов А.П., Рассказ старшего садовника, [w:] http://chehov.niv.ru/chehov/text/ rasskaz-starshego-sadovnika.htm [dostęp: 20.05.2018].

Щемелева Н., Доктор Ф.П. Гааз - человек подвига, „Филокартия” 2015, февраль, nr 1 (41), ss. 42-43.

Яновский А.Е., Говард Джон, [w:] Энщиклопедический словарь Брогкауза и Эфорна в 89-ти томах, t. IX, Санкт-Петербург 1893, ss. 7-9.

\section{References}

Anonymus, "Bozhii chelovek" doktor Gaaz [The God's man doctor Haass], "Istina i zhizn"” [Truth and Life], pp. 34-38.

Anonymus, Katolicheskaia tserkov' prichislila doktora Gaaza k liku blazhennykh [The Catholic Church has nominated Dr. Haas to be the blessed], Available at: https://www.miloserdie.ru/news/katolicheskaya-tserkov-prichislila-doktoragaaza-k-liku-blazhennyh/ [accessed: 20.05.2018].

Chekhov A.P., Rasskaz starshego sadovnika [The story of the Senior gardener], Available at: http://chehov.niv.ru/chehov/text/rasskaz-starshego-sadovnika. htm [accessed: 20.05.2018]. 
Dostojewski F., Idiota [The Idiot], trans. J. Jędrzejewicz, Warszawa, Państwowy Instytut Wydawniczy, 1961.

Feofanov Iu., ,, Tiuremnyi doktor” Fedor Petrovich Gaaz ["Prison Doctor" Fedor Petrovich Gaaz], "Rossiiskaia Federatsiia segodnia: Obshchestvenno-politicheskii zhurnal Federal'nogo sobraniia parliamenta RFN" [Russian Federation Today: a journal of the socio-political federal meeting of the Federal Assembly of the Russian Federation] 2007, no. 22, pp. 58-59.

Gaaz F.P., Prizyv $k$ zhenshchinam [Appeal to women]. Posmertnoe izdanie, per. s frantsuzskogo L.M. Nikoforov, Moskva, Tipogafiia I.I. Kushnerev, 1897.

Gaaz F.P., Azbuka khristianskogo blagonraviia [ABC of the Christian goodness], Moskva 1898.

Grando A., Fedor Gaaz: Schast'e - delat'schastlivym drugikh [Happiness-make others happy], "Meditsinskaia gazeta" [Medical Journal] 1977, no. 61.

Ianovskiii A.E., Govard Dzhon [Howard John], [in:] Entsiklopedicheskii slovar' Brogkauza i Eforna v 89-ti tomakh [Encyclopedic dictionary of Brogkauz and Efron in 89 volumes], vol. IX, Sankt-Peterburg 1893, pp. 7-9.

Hołownia S., Stuga Boży Friedrich Joseph Haas (1780-1853) [Servant of God Friedrich Joseph Has], [in:] idem, Święci pierwszego kontaktu [Saints of first contact], Kraków, Znak, 2017.

Kalikinskaia E., Tiuremnyi doktor Gaaz: bezumnyi filantrop i pomoshchnik osuzhdennykh [Prison Doctor Gaaz; a mad philanthropist and helper of convicts], „Argumenty i fakty” [Arguments and Facts] 2013, no 45, Available at: http:// www.aif.ru/society/history/1017397 [accessed: 20.05.2018].

Katolicheskaia tserkov' prichislila doktora Gaaza k liku blazhennykh [The Catholic Church has nominated doctor Haass to be blessed], Available at: https://www. miloserdie.ru/news/katolicheskaya-tserkov-prichislila-doktora-gaaza-k-likublazhennyh/ [accessed: 20.05.2018].

Kerzum A.P., Obshchestvo popechitel'noe o tiur'makh [Society of custody of prisons], Available at: http://encblago.lfond.spb.ru/showObject.do?object=2823335121 [accessed: 20.05.2018].

Kharlamov E.V., Posledovateli sviatogo doktora Gaaza [Followers of the holy doctor Haass], [in:] E.V. Kharlamov, E.K. Skliarova, O.F. Kiseleva, Dolg vracha i grazhdanina [Debt of doctor and citizen], Rostov-na-Donu: Mini Taip, 2018, 215 pp.

Kollektiv avtorov, Obshchina sester miloserdiia "Utoli moia pechali" [Community of Sisters of Mercy "Quench my sorrow"], Available at: https://fil.wikireading. ru/57270 [accessed: 20.05.2018].

Koni A.F., Fedor Petrovich Gaaz. Bibliograficheskii ocherk [Fedor Petrovich Gaaz. Bibliographic essay], Moskva, Sestrichestvo vo imia prepodobnomuchenitsy velikoi kniagini Elizavety, 2006, 240 pp. 
Kopelev L., Sviatoi doktor Fedor Petrovich [Saint Doctor Fedor Petrovich], Moskva, Tsentr knigi Rudomino, 2013, 222 pp.

Lebedeva B., Speshite delat'dobro [Hurry to do good], "Khristianskaia gazeta «Dlia Tebia»" [Christian Journal "For you"] 2002, no 56, Available at: http://www. foru.ru/article.159.html [accessed: 20.05.2018].

Messel' M.A., Iz istorii skoroi meditsinskoi pomoshchi $v$ Rossii [From the history of emergency care in Russia], "Sovetskoe zdravokhranenie" [Soviet health care] 1960, no. 9, pp. 53-58.

Moskovskii ochag miloserdiia. Sviatoi doktor Gaaz. Sbornik k 230 - letiiu so dnia rozhdeniia F.P.Gaaza [Moscows bonfire of mercy. Saint doctor Gaaz. A collection on the occasion of the $230^{\text {th }}$ anniversary of the birth of F.P. Gaaz], Moskva, Izdatel'stvo dom Tonchu, 2010, $444 \mathrm{pp}$.

Murzina M., "U Gaaza net otkaza". Znamenityi stolichnyi doktor izlechival vsekh ["Gaaz never refuses". Famous metropolitan doctor treats everybody], "Argumenty i fakty" [Arguments and Facts] 2014, no. 19, Available at: http:// www.aif.ru/society/history/u_gaaza_net_otkaza_znamenityy_stolichnyy_doktor_izlechival_vseh [accessed: 20.05.2018].

Perepiska knjazja P. A. Vjazemskogo s A. I. Turgenevym 1812-1819 [Correspondence of Prince P.A. Vyazemsky and A.I. Turgenev 1812-1819], [in:] Ostaf'evskij arhiv knjazej Vjazemskih [Ostafyevsky archive of princes Vyazemsky], vol. 1, ed. V.I. Saitov, Sankt-Peterburg, Izd. S.D. Sheremet'eva, 1899.

Perepiska knjazja P. A. Vjazemskogo s A. I. Turgenevym. 1824-1836 [Correspondence of prince P.A. Vyazemsky and A.I. Turgenev 1824-1836], [in:] Ostaf'evskij arhiv knjazej Vjazemskih [Ostafyevsky archive of princes Vyazemsky], vol. 3, ed. V.I. Saitov, Sankt-Peterburg, Izd. S.D. Sheremet'eva, 1899.

Perepiska knjazja P. A. Vjazemskogo s A. I. Turgenevym. 1837-1845 [Correspondence of prince P.A. Vyazemsky and A.I. Turgenev 1837-1845], [in:] Ostaf'evskij arhiv knjazej Vjazemskih [Ostafyevsky archive of princes Vyazemsky], vol. 4, ed. V.I. Saitov, Sankt-Peterburg, Izd. S.D. Sheremet'eva, 1899.

Petrov G., F. P. Gaaz. Drug obezdolennykh [Friend of disadvantaged persons], Moskva, Sytin, 1902, 39 pp.

Przełomiec M., Święty doktor z Moskwy [Holy doctor form Moscow], "Przewodnik Katolicki" [Catholic Guide], Available at: https://www.przewodnik-[katolicki. pl/Archiwum/2016/Przewodnik-Katolicki-8-2016/Wiara-i-Kosciol/Swietydoktor-z-Moskwy [accessed: 20.05.2018].

Shchemeleva N., Doktor F.P. Gaaz - chelovek podviga [Doctor F.P. Gaaz - a man of an unusual deed], "Filokartiia" [Philocarty] 2015, fevral', no. 1 (41), pp. 42-43. 
Sosnitskii A. "Dobryi doktor”, "drug neschastnykh” Fedor Petrovich Gaaz [Good doctor and a friend of the unfortunate Fedor Petrovich Gaaz], Moskva, Oksakovskaia, 1900, 64 pp.

Varzhapetian V., 10 interesnykh faktov o doktore Gaaze [10 interesting facts about doctor Haass], Available at: http://xn--80aqecdrlilg.xn--p1ai///doktor-gaaz / [accessed: 10.05.2018].

Varzhapetian V., Doktor Gaaz [Doctor Gaaz], Moskva, Izdatel'stvo Frantsiskantsev, 2018, Available at: https://7books.ru/vardvan-varzhapetyan-doktor-gaaz/ [accessed: 20.05.2018].

Varzhapetian V.V., Trinadtsataia strast' [Thirteenth passion], Moskva, Sovremennik, 1988.

Vashkau N.E. "Sviatoi doktor" Fedor Petrovich Gaaz ["Saint Doctor" Fedor Petrovich Gaaz], "Vestnik Volgogradskogo gosudarstvennogo universiteta. Seriia 4. Istoriia" [Bulletin of Volgograd State University. Series 4. History] 2012, no. 2 (22), pp. 26-31.

Velichko S., Doktor Gaaz: filantrop v volchei shube [Doctor Gaaz: Philanthrope in a wolfs skin], Available at: https://www.miloserdie.ru/article/kto-posadil-v-butyrke-topolya/ [accessed: 20.05.2018].

Voznesenskii S. A., Dobryi doktor Gaaz [Good Doctor Gaaz], "Moskva. Zhurnal russkoi kul'tury" [Moscow. Russian Culture Magazine] 2004, no. 12, pp. 212218.

Wollensak G., Friedrich Josef Haas- der heilige Doktor von Moskau [Friedrih Joseph Gaaz: Saint Doctor from Moscow], "Klinische Monatsblatter fur Augenheilkunde“ 2005, no. 222, pp. 513-515. 
